Article

\title{
L-Quebrachitol Promotes the Proliferation, Differentiation, and Mineralization of MC3T3-E1 Cells: Involvement of the BMP-2/Runx2/MAPK/ Wnt/ $\beta$-Catenin Signaling Pathway
}

\author{
Thanintorn Yodthong ${ }^{1}$, Ureporn Kedjarune-Leggat ${ }^{2}{ }^{(0)}$, Carl Smythe ${ }^{3}(\mathbb{O}$, \\ Rapepun Wititsuwannakul ${ }^{4}$ and Thanawat Pitakpornpreecha $1, *$ (D) \\ 1 Department of Biochemistry, Faculty of Science, Prince of Songkla University, Hat-Yai, \\ Songkhla 90110, Thailand; thanintorn.y@gmail.com \\ 2 Department of Oral biology and Occlusion, Faculty of Dentistry, Prince of Songkla University, Hat-Yai, \\ Songkhla 90110, Thailand; ureporn.1@psu.ac.th \\ 3 Department of Biomedical Science, University of Sheffield, Sheffield, England S10 2TN, UK; \\ c.g.w.smythe@sheffield.ac.uk \\ 4 Center of Excellence in Natural Rubber Latex Biotechnology Research and Development, \\ Prince of Songkla University, Hat-Yai, Songkhla 90110, Thailand; wrapepun@yahoo.com \\ * Correspondence: thanawat.psu@gmail.com; Tel.: +66-742-882-65
}

Academic Editors: Atanas G. Atanasov, Karel Šmejkal and Elke Heiss

Received: 22 October 2018; Accepted: 21 November 2018; Published: 26 November 2018

\begin{abstract}
Osteoporosis is widely recognized as a major health problem caused by an inappropriate rate of bone resorption compared to bone formation. Previously we showed that D-pinitol inhibits osteoclastogenesis but has no effect on osteoblastogenesis. However, the effect on osteoblast differentiation of its isomer, L-quebrachitol, has not yet been reported. The purpose of this study was, therefore, to investigate whether L-quebrachitol promotes the osteoblastogenesis of pre-osteoblastic MC3T3-E1 cells. Moreover, the molecular mechanism of action of L-quebrachitol was further explored. Here, it is shown for the first time that L-quebrachitol significantly promotes proliferation and cell DNA synthesis. It also enhances mineralization accompanied by increases in mRNA expression of bone matrix proteins including alkaline phosphatase (ALP), collagen type I (ColI), osteocalcin (OCN), and osteopontin (OPN). In addition, L-quebrachitol upregulates the mRNA and protein expression of bone morphogenetic protein-2 (BMP-2) and runt-related transcription factor-2 (Runx2), while down-regulating the receptor activator of the nuclear factor- $\kappa \mathrm{B}$ ligand (RANKL) mRNA level. Moreover, the expression of regulatory genes associated with the mitogen-activated protein kinase (MAPK) and wingless-type MMTV integration site (Wnt) / $\beta$-catenin signaling pathways are also upregulated. These findings indicate that L-quebrachitol may promote osteoblastogenesis by triggering the BMP-2-response as well as the Runx2, MAPK, and $\mathrm{Wnt} / \beta$-catenin signaling pathway.
\end{abstract}

Keywords: L-quebrachitol; Osteoblastogenesis; Wnt/ $\beta$-Catenin; BMP-2; Runx2; MAPK

\section{Introduction}

Osteoporosis is a highly prevalent bone disease that results from inappropriate bone remodeling caused by an imbalance between osteoclastic bone degradation and osteoblastic bone regeneration. The condition is characterized by decreased bone mass and degeneration of bone architecture, which results in decreased bone strength and increased susceptibility to fractures. The World Health Organization (WHO) considers osteoporosis to be a major health problem as it affects over 200 million 
people worldwide [1]. Age-related bone loss, which affects approximately $50 \%$ of women and $25 \%$ of men over 50 years old, is the most important lifetime risk factor for having an osteoporosis-related fracture [2].

The strategy for treatment of osteoporosis is to enhance bone formation through an induction of osteoblastogenesis by increasing osteoblast proliferation and differentiation with an anabolic agent such as estrogen, and/or the reduction of osteoclastogenesis with anti-resorptive drugs, such as a bisphosphonate. However, despite being effective, treatment with estrogen and bisphosphonate is associated with serious side effects, such as ovarian carcinogenesis and bone quality reduction. Therefore, research has focused on identifying suitable diets or supplements, particularly those derived from natural resources to prevent osteoporosis [3].

Multiple signaling pathways, including runt-related transcription factor 2 (Runx2), osterix (Osx), bone morphogenic protein (BMP), mitogen-activated protein kinase (MAPK), and the wingless-type MMTV integration site $(\mathrm{Wnt}) / \beta$-catenin pathways, regulate the proliferation and differentiation of osteoblasts and thus are involved in controlling bone formation. In addition, the increased expression of bone matrix proteins, such as alkaline phosphatase (ALP), type I collagen (ColI), and osteopontin (OPN) also stimulate mineralization and lead to bone formation [4]. Osteoblasts not only regulate bone formation but also control bone resorption by modulating osteoclastogenesis via osteoprotegerin $(\mathrm{OPG})$ / receptor activator of nuclear factor- $\mathrm{K} B$ ligand (RANKL)/ receptor activator of nuclear factor- $\mathrm{k} B$ (RANK) system [4].

Many plant-based compounds have been found to promote osteoblastogenesis-induced bone formation, including glycosides, flavonoids, terpenoids, coumarins, phenols, phenolics acids, and others. Moreover, molecular mechanisms and various cellular targets have been identified, including the control of transcription factors, bone-specific protein, signal pathways, and the OPG/RANKL system [3]. Among compounds derived from natural resources, some simple carbohydrates are also potential candidates as an alternative treatment or form of prevention against osteoporosis. However, their anti-osteoporosis pharmacological mechanism is basically related to the reduction of bone resorption. Both polymeric and monomeric sugars have shown promising activity on the suppression of osteoclastogenesis. For example, $\beta$-Glucans, polymers of D-glucose linked via $\beta-(1,3)$, $\beta-(1,4)$, or $\beta-(1,6)$-glycosidic bonds, from the mushroom, Pleurotus citrinopileatus, inhibit osteoclast differentiation and activity through inhibition of RANKL and tartrate-resistant acid phosphatase, respectively. In addition, $\beta$-glucans from the fungus, Aureobasidium pullulans, exhibit effects on bone metabolism both in vivo and in vitro. In ovariectomized rats, an animal model for postmenopausal osteoporosis [5], $\beta$-glucans suppresses bone loss while the exposure of pre-osteoblastic MC3T3-E1 cells to $\beta$-glucans enhances their proliferation and mineralization [6].

Osteoclast differentiation is also regulated by various monomeric sugars via different molecular mechanisms. High glucose concentrations inhibit osteoclastogenesis through the suppression of RANKL-induced generation of reactive species (ROS) [7] and the reduced expression of several genes involved in differentiation, such as NFATc1 [8]. The rare aldohexose, allose, inhibits osteoclast differentiation via the strong induction of thioredoxin-interacting protein (TXNIP) which, in turn, modulates the thioredoxin-regulated gene transcription [9]. Recently, the amino sugars glucosamine $(\mathrm{GLcN})$ and its acetyl derivative, $N$-acetyl glucosamine (GLcNAc), have been shown to suppress osteoclast differentiation through the promotion of $O-G l c N A c y l a t i o n[10,11]$. GLcN not only suppresses osteoclastogenesis but also promotes osteoblastogenesis and increases autophagy by inhibiting the mammalian target of the rapamycin (mTOR) pathway [12]. Moreover, the intake of GLcN reduces bone loss in ovariectomized mice by suppressing osteoclast function [13]. The intracellular sugar, inositol and its derivatives, which act as essential messenger molecules in signal transduction, have recently been demonstrated to affect bone metabolism. Inositol hexakisphosphate (IP6), the major intracellular phosphorylated form of inositol, has been reported not only to block the mineralization of MC3T3-E1 osteoblasts, but also have a selective inhibitory effect on osteoclast formation [14]. The inhibition of osteoblast mineralization is brought about by neutralizing crystal growth and promoting the expression of the mineralization inhibitor osteopontin, without impairment 
of other specific bone matrix proteins [15]. Ca-Mg-IP6 consumption has been shown to bring about a reduction in bone loss of ovariectomized rats [16]. D-pinitol (3-O-methyl-D-chiro-inositol), is one of the natural occurring derivatives of inositol. It has been reported to suppress RANKL-induced osteoclastogenesis and protect bone loss in the ovariectomy animal model but has no effect on the proliferation and differentiation of osteoblast cells [17].

L-quebrachitol (2-O-methyl-L-chiro-inositol) is a naturally-occurring, optically-active methoxy analog of inositol (Figure 1). In addition to the many plants that are reported to contain this compound, the serum of rubber latex has a particularly high concentration, suggesting that L-quebrachitol could be recovered as a byproduct from the rubber industry. L-quebrachitol has acquired increasing interest as a starting material in the chiral synthesis of various biologically active compounds. In addition, it has been reported to have various biological activities, including free-radical scavenging, gastroprotection, anti-platelet aggregation, and anti-diabetic activity [18]. Its isomer, D-pinitol (Figure 1), possesses inhibitory activity against osteoclastogenesis without any effect on osteoblastogenesis [17]. Although they have the same chemical structures, most isomers demonstrate marked differences in biological activities such as pharmacology, toxicology, metabolism, and pharmacokinetics [19]. Because L-quebrachitol has not yet been investigated for any effect on either osteoclastogenesis or osteoblastogenesis, the aim of this study is to investigate the effect of L-quebrachitol on the proliferation and differentiation of the murine pre-osteoblastic cell line MC3T3-E1 and explore the molecular mechanism by which L-quebrachitol promotes osteoblastogenesis. In addition, we also explore a method to obtain the purified L-quebrachitol as a by-product from the serum obtained along with the rubber sheeting process.<smiles>O[C@H]1[C@H](O)[C@@H](O)[C@H](O)[C@@H](O)[C@H]1O</smiles>

A<smiles>CO[C@H]1[C@@H](O)[C@H](O)[C@@H](O)[C@H](O)[C@H]1O</smiles>

B<smiles>CO[C@H]1[C@@H](O)[C@H](O)[C@@H](O)[C@H](O)[C@H]1O</smiles>

C

Figure 1. The structures of D-chiro-inositol (A), D-pinitol (B) and L-quebrachitol (C).

\section{Results}

\subsection{Extraction and Purification of L-quebrachitol from Rubber Latex Serum}

Our study demonstrated a method for the recovery and purification of L-quebrachitol as a by-product from the rubber sheeting process. Briefly, fresh latex (7 L) was coagulated by addition of formic acid, squeezed to obtain 3.5 L of the serum, which was further fractionated by molecular size-dependent differential filtration. The permeate arising from the use of a $10 \mathrm{kDa}$ filter membrane was further fractioned using a $1 \mathrm{kDa}$ membrane. The resultant permeate $(3.5 \mathrm{~L})$ was concentrated by spray-drying to obtain $100 \mathrm{~g}$ of dried powder, then extracted with ethanol, before ionic impurities were removed by cation-exchange chromatography. The purified L-quebrachitol was characterized analytically by comparison of chromatographic and spectroscopic data, including mass, IR, and NMR spectra with a commercial standard preparation (Sigma-Aldrich, Missouri). The yield (means $\pm S E M$, $n=5$ ) of L-quebrachitol was $0.92 \pm 0.22 \mathrm{~g} / \mathrm{L}$ of fresh latex or $1.85 \pm 0.45 \mathrm{~g} / \mathrm{L}$ of serum.

\subsection{L-quebrachitol Enhances the Cell Viability of Pre-Osteoblastic MC3T3-E1 Cells}

Using an MTT assay which measures metabolic activity as a surrogate indicator of cell viability, cells were exposed to a range of L-quebrachitol concentrations for $24-72 \mathrm{~h}$. The results obtained at 24 and $48 \mathrm{~h}$ after exposure indicated that L-quebrachitol is not only not cytotoxic to pre-osteoblastic MC3T3-E1 cells at concentrations ranging from 0.001 to $1000 \mu \mathrm{g} / \mathrm{mL}$, but also that it significantly increased cell proliferation in a broadly concentration-dependent manner from 0.01 to $100 \mu \mathrm{g} / \mathrm{mL}$. However, L-quebrachitol-mediated cell proliferation decreased to control 
levels by $72 \mathrm{~h}$, perhaps reflecting a limiting effect of cell density on proliferation. At very high concentrations $(1000 \mu \mathrm{g} / \mathrm{mL})$, L-quebrachitol showed some toxicity towards these cells, reducing cell numbers by about $20 \%$ after $72 \mathrm{~h}$ of exposure (Figure 2 ).

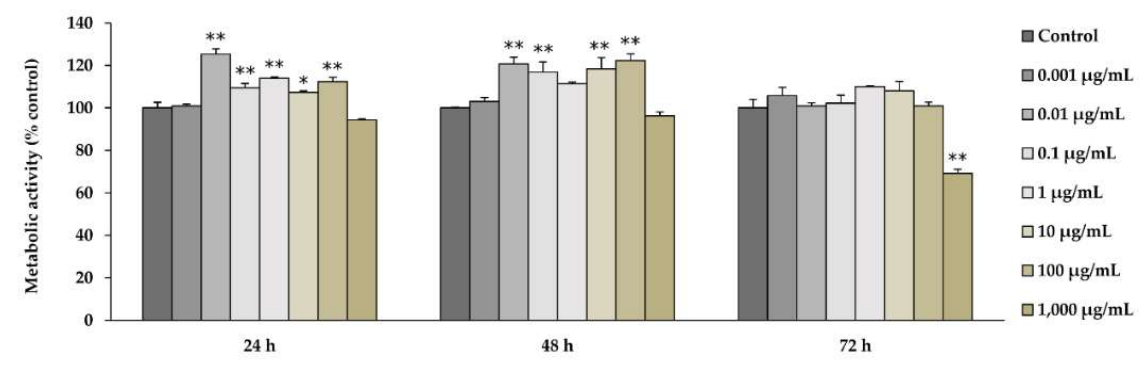

Figure 2. The effect of L-quebrachitol on the cell viability of MC3T3-E1 cells. MC3T3-E1 cells were treated with L-quebrachitol at various concentrations for 24,48 , and $72 \mathrm{~h}$. Cell viability was measured by MTT assay. A representative example of 3 independent experiments. Each data point represents the means of 4 replicate samples \pm SEM. ${ }^{*} p<0.05$ and ${ }^{* *} p<0.01$ when compared with the control.

\subsection{L-quebrachitol Promotes Cell DNA Synthesis}

To further understand the effects of L-quebrachitol on proliferation, we examined the effect on cell cycle progression, by the determination of the percentage of cells in each cell cycle phase (G0/G1, S, and G2/M) by flow cytometry after treatment with various concentrations of L-quebrachitol. The results indicated that the proportion of cells in the G0/G1 phase was significantly decreased after treatment with $0.001,0.01,0.1,1$, and $10 \mu \mathrm{g} / \mathrm{mL}$ of L-quebrachitol for $48 \mathrm{~h}$, whereas the percentage of cells in $S$ phase was significantly increased. These results suggest that progression into S-phase is promoted by L-quebrachitol (Figure 3A,B).

(A)
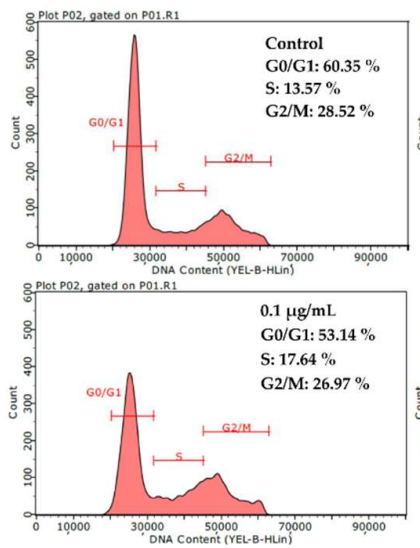

(B)
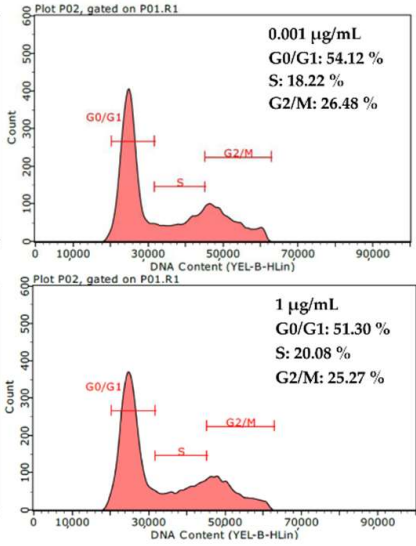
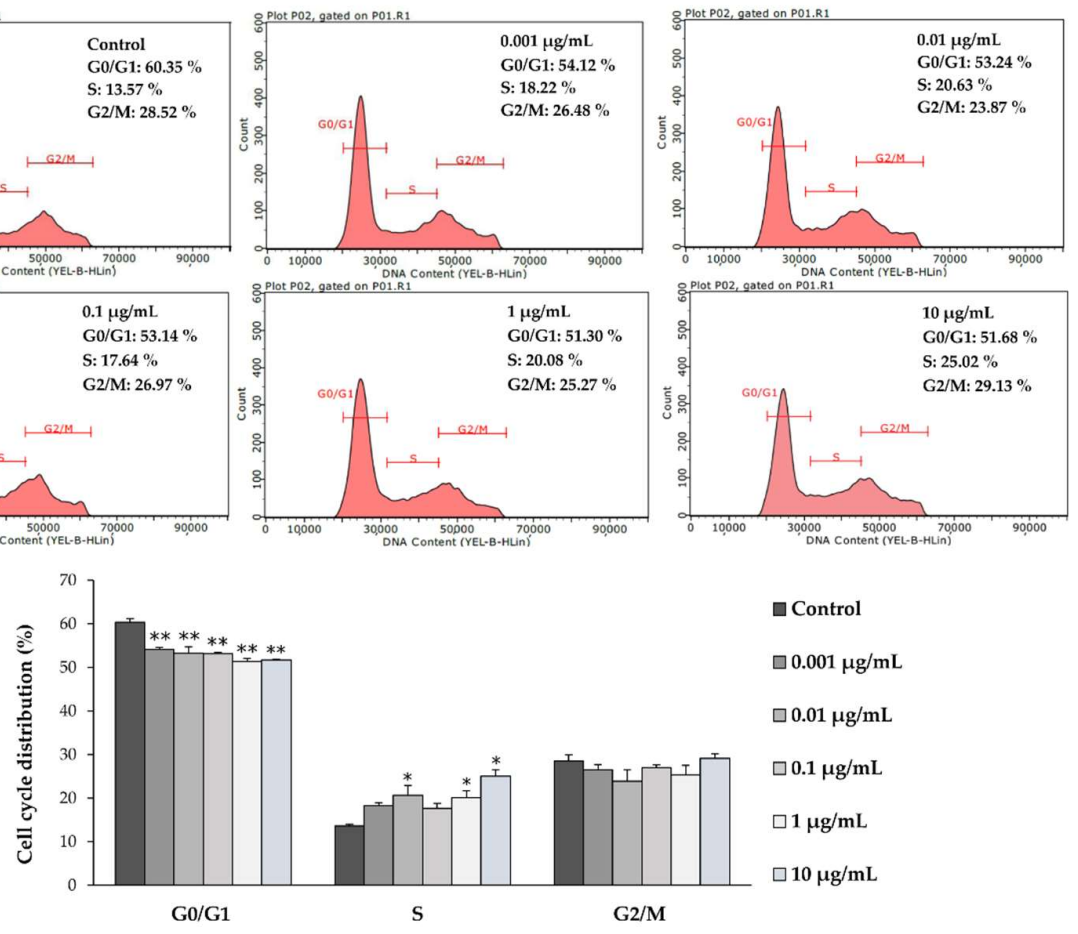

- Control

$001 \mu \mathrm{g} / \mathrm{mL}$

$\mu \mathrm{g} / \mathrm{mL}$

Figure 3. (A) The flow cytometry analysis of MC3T3-E1 cells after treatment with L-quebrachitol at concentrations of $0.001,0.01,0.1,1$, and $10 \mu \mathrm{g} / \mathrm{mL}$ for $48 \mathrm{~h}(\mathbf{B})$. The percentage of the total cell population at each phase of the cell cycle is represented by a bar diagram. A representative example of 3 independent experiments. Each data point represents the means of 3 replicate samples \pm SEM. ${ }^{*} p<0.05$ and ${ }^{* *} p<0.01$ when compared with the control. 


\subsection{L-quebrachitol Promotes Differentiation and Mineralization of Osteoblast Cells}

The pre-osteoblastic MC3T3-E1 cells were induced to differentiate with an osteogenic medium and the effect of L-quebrachitol on cell differentiation was evaluated. Matrix mineralization was assessed by visualizing the extent of the Alizarin Red S staining of cellular calcium deposits after cells were incubated with various concentrations of L-quebrachitol for 14 or 21 days. The amount of calcium deposit markedly increased with L-quebrachitol concentrations of 0.1 and $1 \mu \mathrm{g} / \mathrm{mL}$ by about 2 to 2.5 times, respectively, compared with the control at 14 days after treatment. However, even though the level of mineralization appeared to have decreased at 21 days compared to that at 14 days, L-quebrachitol concentrations of $0.001-1 \mu \mathrm{g} / \mathrm{mL}$ still augmented the amount of calcium deposit compared to the control at 21 days. Alizarin Red S staining observed in Figure 4A was quantified (Figure 4A,B), confirming the increase observed at $0.1-1 \mu \mathrm{g} / \mathrm{mL}$ after 14 days of exposure. In addition, alkaline phosphatase, the early-stage biomarker for matrix maturation [20], was also measured following treatment with L-quebrachitol for 7 days, demonstrating that L-quebrachitol concentrations of $0.01-1 \mu \mathrm{g} / \mathrm{mL}$ significantly increased the cellular ALP activity (Figure 4C). Taken together, these results indicate that L-quebrachitol significantly enhances the differentiation and matrix maturation of osteoblastic cells.

(A)

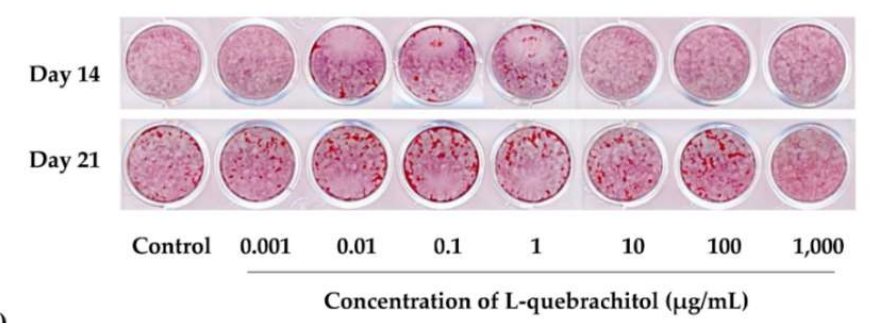

(B)

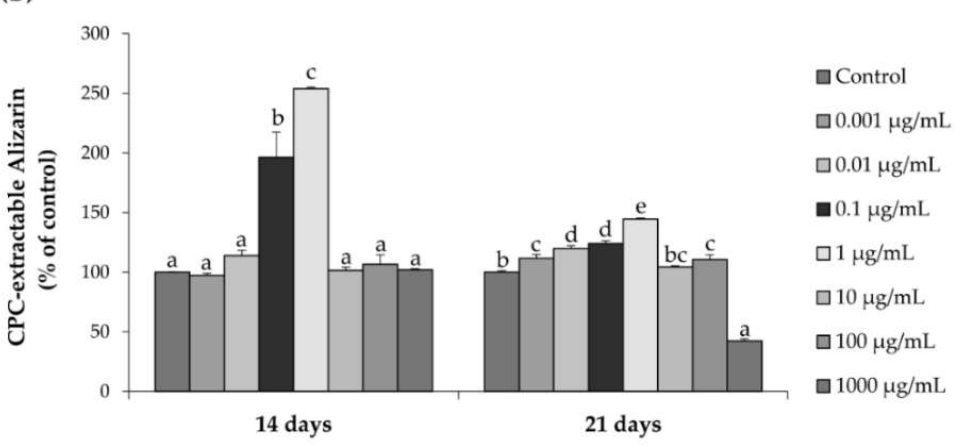

(C)

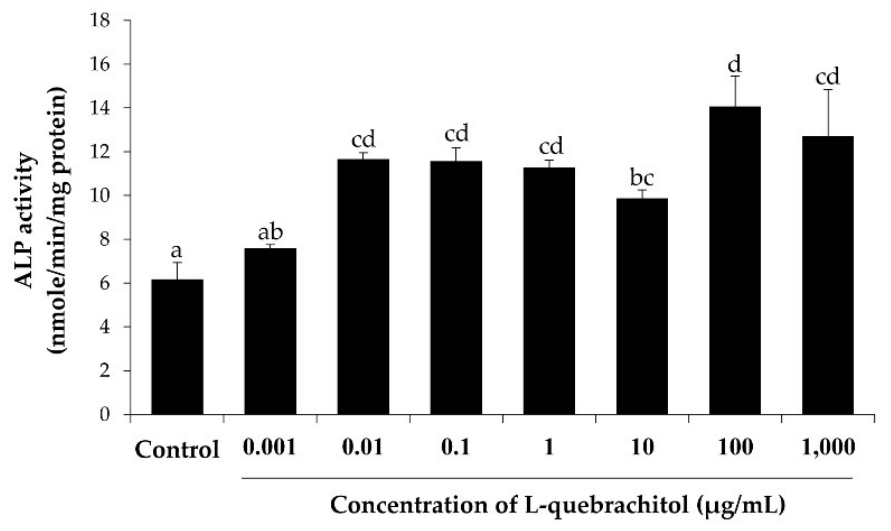

Figure 4. The effect of L-quebrachitol at the concentration of $0.001,0.01,0.1,1,10,100$, and $1000 \mu \mathrm{g} / \mathrm{mL}$ on osteogenic differentiation and mineralization in MC3T3-E1 cells. (A) MC3T3-E1 cells were treated 
with L-quebrachitol for 14 and 21 days. The cells were stained with Alizarin Red S to observe the production of mineralization (B) Quantification of Alizarin Red S staining extracted by cetylpyridinium chloride. (C) Alkaline phosphatase (ALP) activity in MC3T3-E1 cells after treatment with L-quebrachitol for 7 days. A representative example of the 3 independent experiments. Each data point represents the means of 4 replicate samples \pm SEM. The data in columns with different letters in each group were significantly different at $p<0.05$.

\subsection{L-quebrachitol Up-Regulates mRNA Expression of BMP-2, Runx2, and Osteogenesis Markers}

To determine the effect of L-quebrachitol on osteoblastic cell differentiation, the expression of genes involved in the formation of the cellular matrix including the early-stage (alkaline phosphatase), middle stage (collagen type 1 and osteopontin), late stage (osteocalcin), and key regulatory (Bone morphogenetic protein-2 and Runt-related transcription factor-2) genes [21] was evaluated by qRT-PCR after treatment with L-quebrachitol. The analysis revealed that L-quebrachitol significantly increased the expression of osteocalcin, osteopontin, runt-related transcription factor-2, and alkaline phosphatase genes after $24 \mathrm{~h}$ exposure, although the optimal concentration for maximal gene expression varied from gene to gene. In contrast, the expression of the collagen type 1 gene seemed to slightly increase after $72 \mathrm{~h}$ of exposure. L-quebrachitol increased the expression of the bone morphogenetic protein-2 gene, which plays a crucial role in the transduction of osteoblastic differentiation and bone formation, with an expression level about 4-fold higher than control at concentrations of 0.01 and $10 \mu \mathrm{g} / \mathrm{mL}$ after $24 \mathrm{~h}$. Consistent with the notion that L-quebrachitol can induce osteoblastic cell differentiation, all the tested concentrations of L-quebrachitol significantly suppressed the expression of RANKL, a major regulatory gene for osteoclastogenesis (Figure 5).
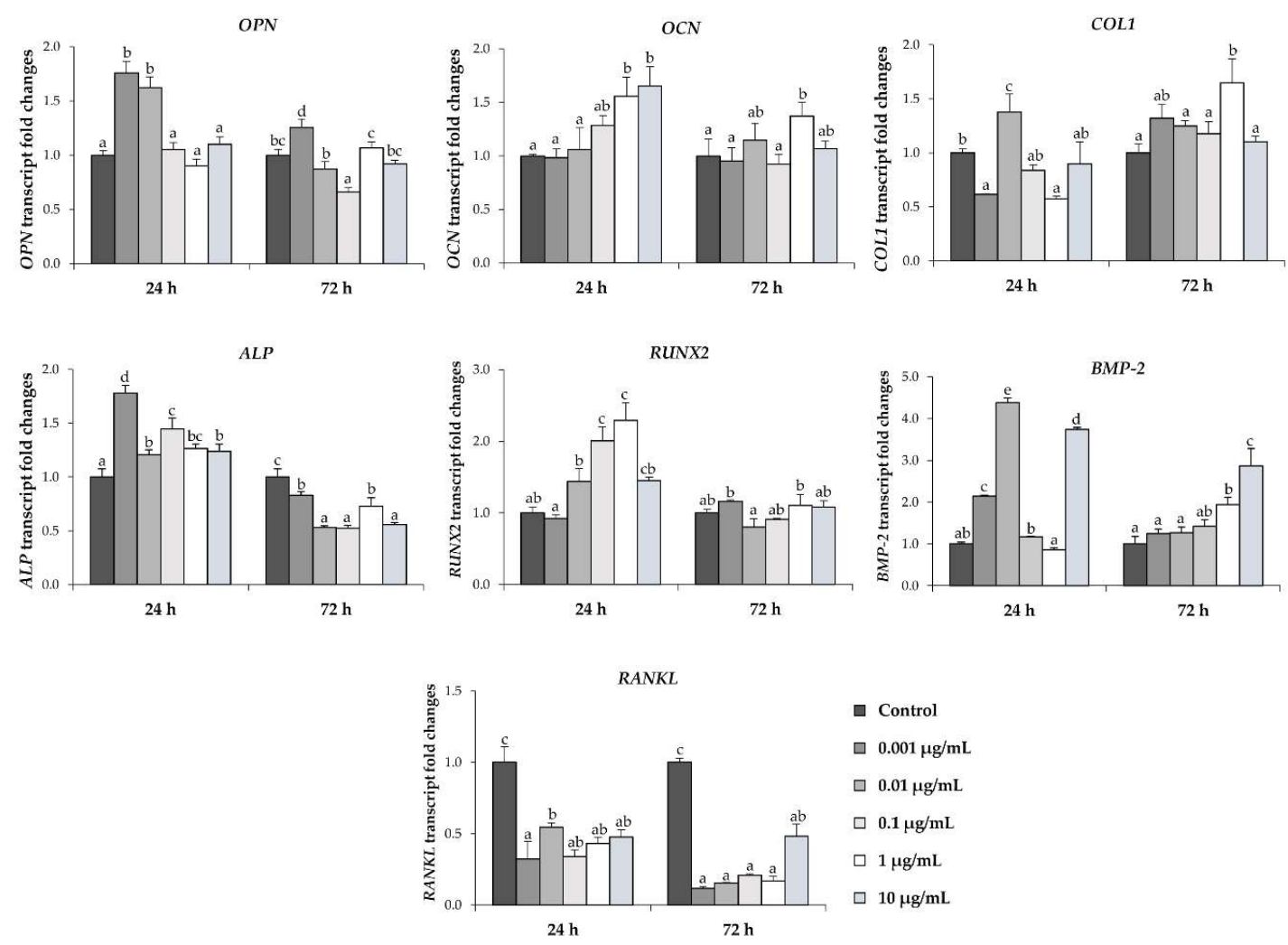

Figure 5. Quantitative real-time PCR was used to analyze the expression of OPN, OCN, COL1, $A L P, R U N X 2, B M P 2$, and RANKL in osteoblast differentiation from MC3T3-E1 cells treated with the various concentrations of L-quebrachitol for 24 and $72 \mathrm{~h}$. A representative example of 3 independent experiments. Each data point represents the means of 4 replicate samples \pm SEM. The data in columns with different letters in each group were significantly different at $p<0.05$. 
2.6. L-quebrachitol Increases Expression of a Gene Involved in the MAPK and Wnt/B-Catenin Signaling Pathways

To investigate the participation of signaling pathways mediating the effect of L-quebrachitol on osteoblast proliferation and differentiation, the expression of mitogen-activated protein kinase (MAPK) family genes, as well as the Wnt/ $\beta$-catenin signaling pathway, were investigated with qRT-PCR. It has been demonstrated that MAPKs play an important role in controlling cell proliferation and differentiation and regulate osteoblast differentiation [22]. The expression of MAPK pathway members such as JNK1, JNK2, ERK1, ERK2, and p38 $\alpha$ was investigated in response to L-quebrachitol. The results indicated that lower concentrations $(0.01$ and $0.1 \mu \mathrm{g} / \mathrm{mL})$ of L-quebrachitol significantly induce ERK1 and ERK2 mRNA level both at 24 and $48 \mathrm{~h}$, while the expression of JNK1 and JNK2 were also up-regulated with 0.01 and $0.1 \mu \mathrm{g} / \mathrm{mL}$ of L-quebrachitol only at $12 \mathrm{~h}$. In addition, $0.01 \mu \mathrm{g} / \mathrm{mL} \mathrm{of}$ L-quebrachitol significantly increased the mRNA level of p38 $\alpha$ at all times tested (Figure 6).

Wnt/ $\beta$-catenin signaling has been demonstrated to regulate both osteoblast differentiation and bone formation [23]. Thus, the expression of genes related to Wnt/ $\beta$-catenin signaling pathway regulators, including LRP5, $\beta$-catenin, Wnt5a, and Fzd4 was investigated with regard to the effect of L-quebrachitol. L-quebrachitol treatment tended to significantly up-regulate the mRNA expression of LRP5, $\beta$-catenin, and Fzd4 at $12 \mathrm{~h}$, whereas the Wnt5a expression level increased and reached the highest level, about 2-fold, with $0.01 \mu \mathrm{g} / \mathrm{mL}$ of L-quebrachitol at $24 \mathrm{~h}$. However, the mRNA expression of all genes tested was found to decrease at $48 \mathrm{~h}$ (Figure 7). Taken together, the L-quebrachitol treatment effectively induces the expression of genes related to $\mathrm{Wnt} / \beta$-catenin signaling pathway regulators at $12-24 \mathrm{~h}$, leading to the enhanced expression of osteoblast differentiation and proliferation markers.
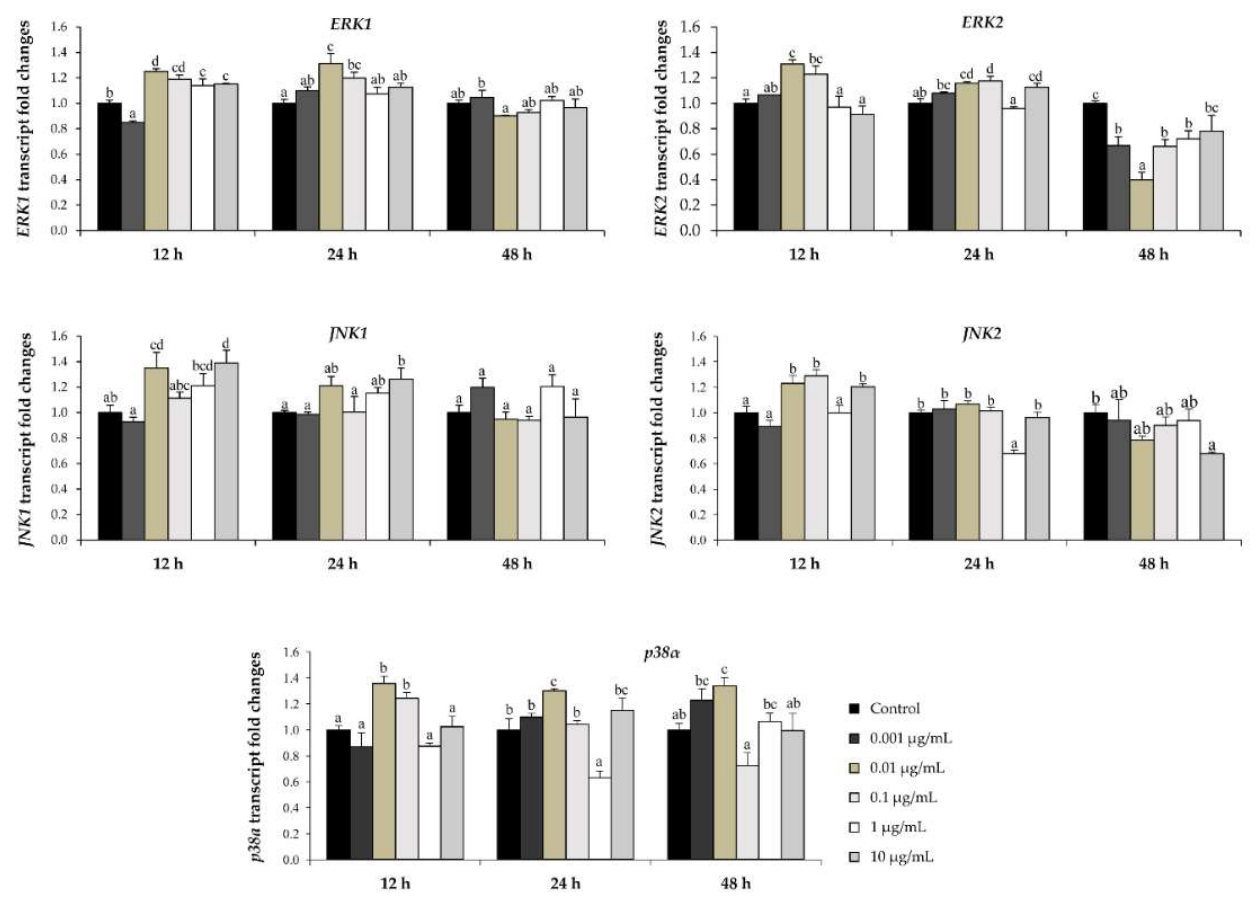

Figure 6. Quantitative real-time PCR was used to analyze the expression of MAPK pathway genes ERK1, $E R K 2, J N K 1, J N K 2$, and $p 38 \alpha$ in osteoblast cells cultured with various concentrations of L-quebrachitol for 24,48 and $72 \mathrm{~h}$. A representative example of 3 independent experiments. Each data point represents the means of 4 replicate samples \pm SEM. The data in columns with different letters in each group were significantly different at $p<0.05$. 

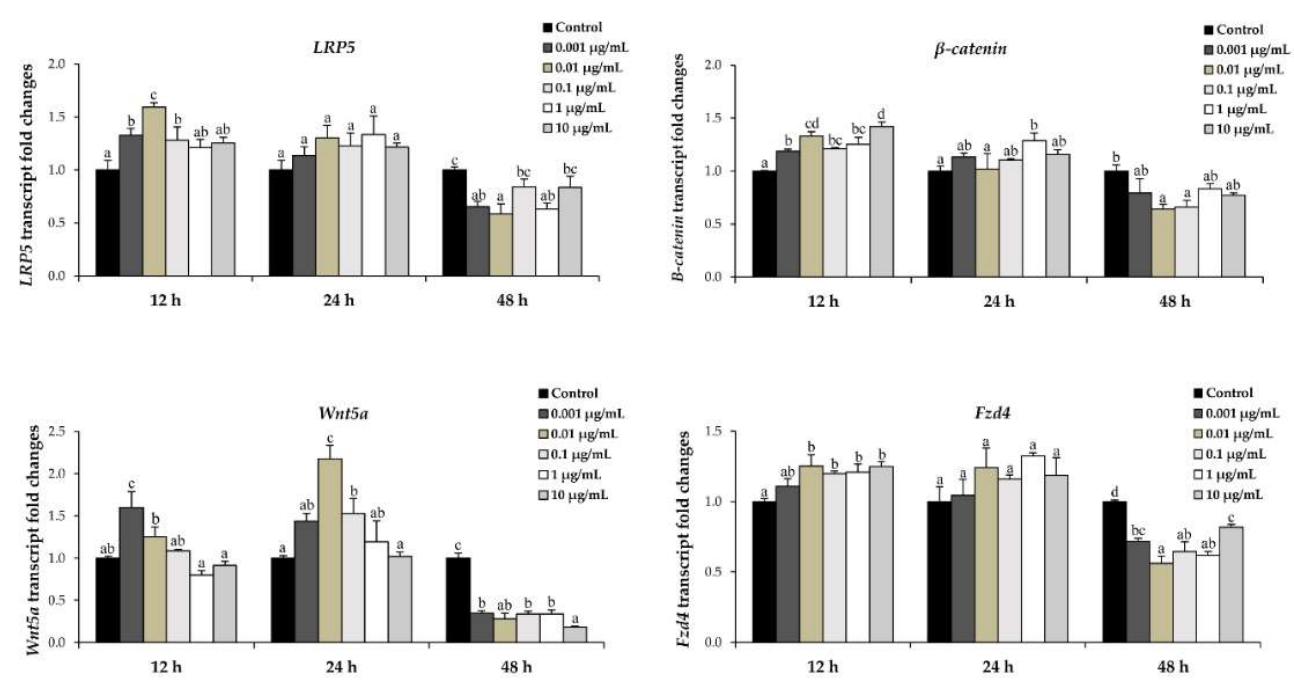

Figure 7. Quantitative real-time PCR was used to analyze the expression of Wnt/ $\beta$-catenin signaling pathway genes LRP5, $\beta$-catenin, Wnt5a, and Fzd4 in osteoblast cells cultured with various concentrations of L-quebrachitol for 24, 48, and $72 \mathrm{~h}$. A representative example of 3 independent experiments. Each data point represents the means of 4 replicate samples \pm SEM. The data in columns with different letters in each group were significantly different at $p<0.05$.

\subsection{Western Blot Analysis of BMP-2 and Runx2 Expression}

To further verify that L-quebrachitol regulates components of the BMP signaling pathway and the expression of the master transcription factor, Runx2, we examined the protein expression of those molecules by Western blot analysis (Figure 8A). L-quebrachitol significantly enhanced the protein level expression of Runx 2 at concentrations of 1 and $10 \mu \mathrm{g} / \mathrm{mL}$ at 10 days (Figure 8A), whereas BMP-2 protein expression significantly increased at 12 days with 1 and $10 \mu \mathrm{g} / \mathrm{mL}$ of L-quebrachitol and gave the highest level, 2-fold compared to the control, at 10 days with $0.01 \mu \mathrm{g} / \mathrm{mL}$ of L-quebrachitol (Figure 8B).
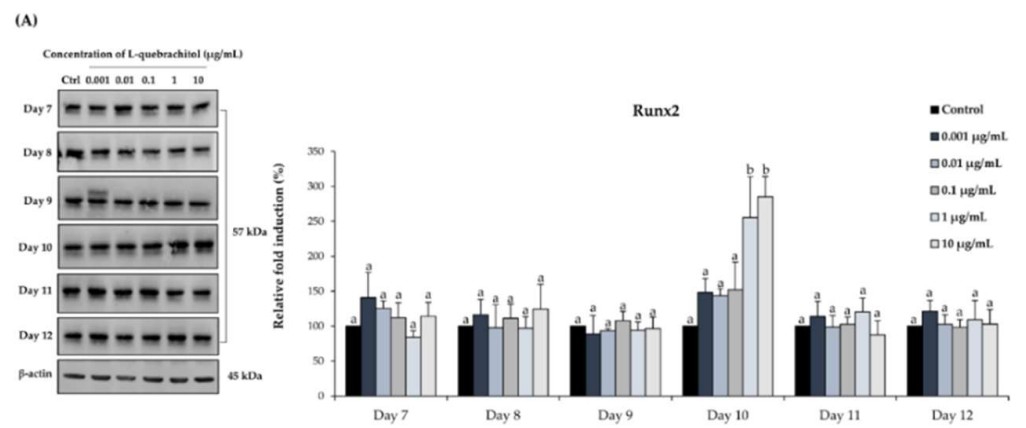

(B)
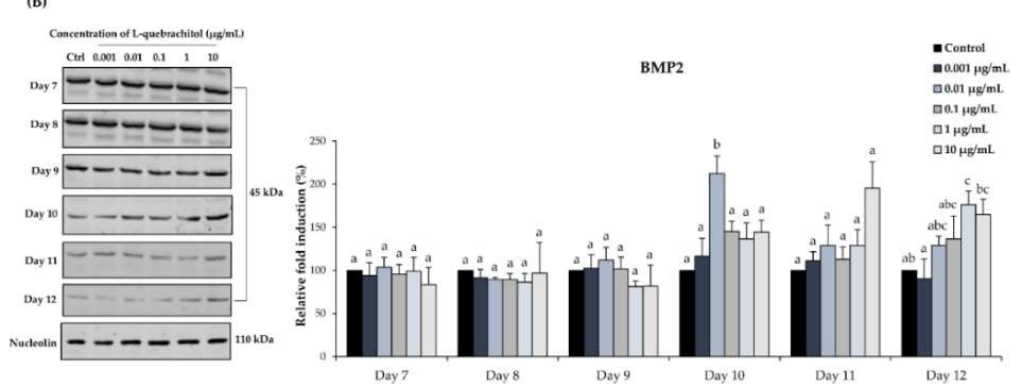

Figure 8. The effects of L-quebrachitol on the protein level expression of Runx2 (A) and bone morphogenic protein 2 (BMP-2) (B). MC3T3-E1 cells were treated with L-quebrachitol at various concentrations for $7,8,9,10,11$, and 12 days. Levels of each protein (A,B, left-hand panels) were determined by Western blotting using cognate antibodies. Quantitation was performed as 
described in Materials and methods and levels expressed relative to the loading control proteins $\beta$-actin (A) and nucleolin (B). A representative example of 3 independent experiments. Each data point represents the means of 3 replicate samples \pm SEM. The data in columns with different letters in each group were significantly different at $p<0.05$.

\section{Discussion}

Previous studies demonstrated that Hevea brasiliensis latex serum is a potential source of a wide range of biologically-active constituents and enzymes [24-28], such as L-quebrachitol [29]. Thus, this study reported an alternative method for the isolation and purification of L-quebrachitol from Hevea brasiliensis latex serum with a recovery yield of $1.85 \pm 0.45 \mathrm{~g} / \mathrm{L}$ of serum, accompanied by chitinolytic enzymes [28] and a rubber sheet product (data not shown).

D-pinitol, an isomer of L-quebrachitol, has been reported to inhibit bone resorption through the suppression of RANKL-induced osteoclastogenesis with no effect on the proliferation and differentiation of osteoblasts [17]. However, the effect of L-quebrachitol on bone formation had not previously been studied. Hence, our study aimed to investigate its effect on osteoblastogenesis and the signaling pathway involved in the osteogenic activity of L-quebrachitol. Our results indicate that treatment with L-quebrachitol at concentrations of $0.01,0.1,1,10$, and $100 \mu \mathrm{g} / \mathrm{mL}$ significantly increased the cell viability of pre-osteoblastic MC3T3-E1 cells at 24 and $48 \mathrm{~h}$ (Figure 2). This is consistent with the results obtained from cell cycle analysis, which indicated that L-quebrachitol promotes the proliferation of cells by increasing cell DNA synthesis (Figure 3).

The BMP signaling pathway is a crucial signaling pathway in bone formation. BMP-2 reportedly acts as a potent inducer of a mature differentiation of pre-osteoblastic cells by regulating Runx2, a transcription factor that is required for bone formation. The activation of $R u n x 2$ further regulates the expression of osteoblast differentiation by increasing alkaline phosphatase (ALP) activity and synthesis of the bone matrix proteins, including collagen type I (ColI), osteocalcin (OCN), and osteopontin $(\mathrm{OPN})$, therefore, inducing bone formation and bone remodeling $[3,30]$. It has been demonstrated that Runx2-null mice have no bone tissue and the reduction in Runx2 expression leads to a decrease in the bone matrix proteins [31]. In this study, L-quebrachitol significantly enhances the expression of BMP2 mRNA after either 24 or $48 \mathrm{~h}$ of exposure (Figure 5), consistent with the subsequent increase in BMP2 protein level at days 10 and 12 (Figure 8B). This is also consistent with an increase in the downstream regulator Runx2, at both mRNA (Figure 5) and protein expression levels (Figure 8A). In addition, the mRNA expression level of ALP, which is the most widely recognized marker of early-stage osteoblastic differentiation and an up-regulator of bone matrix genes, including Coll and OPN [32], is transiently increased at $24 \mathrm{~h}$ (Figure 5) consistent with the increase in ALP activity observed at 7 days (Figure $4 \mathrm{C}$ ). Moreover, other bone matrix proteins, OCN, OPN, and ColI are also up-regulated at the mRNA level (Figure 5). Together, this leads to the enhancement of the late stage of osteoblastic differentiation, observed by the Alizarin Red $\mathrm{S}$ staining of the calcium deposit in mature osteoblasts at 14 days (Figure 4A,B). Hence, L-quebrachitol most likely promotes and up-regulates osteoblast maturation and differentiation from the early to the late stages through the BMP signaling pathway.

The canonical Wnt/ $\beta$-catenin signaling pathway is one established pathway which plays a pivotal role in bone formation by modulating proliferation, differentiation, and mineralization in osteoblastogenesis. The Wnt/ $\beta$-catenin signaling pathway is activated when extracellular Wnt ligands bind to frizzled receptors (Fzds) and its co-receptors LRP5 and LRP6, leading to a cascade of phosphorylation. This, in turn, results in destabilization of an intracellular protein complex facilitating a release of $\beta$-catenin which translocates into the nucleus, thus activating target gene expression mediated by TCF/LEF $[33,34]$. In addition, canonical Wnt/ $\beta$-catenin signaling is active in various osteoblast or pre-osteoblastic cell lines such as MC3T3-E1 and cooperatively controls the osteoblast differentiation and bone formation via crosstalk with the BMP signaling pathway, suggesting that the Wnt/ $\beta$-catenin signaling pathway is an upstream activator of BMP2 expression in osteoblasts [22]. Previously, it has been reported that the deactivation of Wnt/ $\beta$-catenin signaling results in decreased 
OPG expression, increased RANKL expression, and the inhibition of osteoblastic differentiation [35]. Moreover, LRP5 mutations cause changes in bone mass and deletion of FZD9 is characterized in part by low bone density [33]. In this study, the qRT-PCR analysis showed that the expression level of LRP5, $\beta$-catenin, Fzd4, and Wnt5a significantly increased after treatment with L-quebrachitol (Figure 7). It was previously reported that the Wnt/ $\beta$-catenin signaling pathway can induce osteoblast differentiation genes, such as ALP, ColI, and OPN [36], demonstrating that those genes are up-regulated following cell exposure to L-quebrachitol. These results suggest that the enhancement of osteoblast differentiation by L-quebrachitol is likely to correlate with the Wnt/ $\beta$-catenin signaling pathway.

MAPKs also play an important role in bone formation. MAPK family proteins, p38 mitogen-activated protein kinases (p38), extracellular signal-regulated kinases (ERK), and jun n-terminal kinase (JNK), are essential factors in the regulation of osteoblast differentiation through the activation of transcriptional factors, such as AP-1 [37]. In addition, p38 activation seems to be critical for the regulation of ALP expression during MC3T3-E1 differentiation [38]. Remarkably, it has been reported that the MAPK pathway is able to control Runx2 and osterix via phosphorylation [39] and MAPK activation can induce Runx2-dependent osteocalcin and osteopontin genes [40]. In our study, L-quebrachitol was associated with the increased expression of the MAPK gene family members JNK1, JNK2, ERK1, ERK2, and $p 38 \alpha$ at the mRNA level (Figure 6), which suggests that L-quebrachitol may possibly promote osteoblast differentiation via the activation of the MAPK signaling pathway.

Osteoblasts additionally control bone resorption by regulating osteoclastogenesis through osteoprotegerin (OPG)/receptor activator of nuclear factor- $\mathrm{B}$ ligand (RANKL)/receptor activator of nuclear factor- $\kappa \mathrm{B}$ (RANK) system. RANKL plays a critical role in the activation of osteoclastogenesis via binding to its receptor RANK [4]. In our study, L-quebrachitol clearly suppresses the RANKL mRNA expression (Figure 5). These results suggest L-quebrachitol not only promotes bone formation through the induction of osteoblastogenesis, but also suppresses osteoclastogenesis through the OPG/RANKL/RANK system.

In summary, we demonstrated for the first time that L-quebrachitol at a low concentration $(0.01 \mu \mathrm{g} / \mathrm{mL}$ or $50 \mathrm{nM})$ can promote osteogenic proliferation, differentiation, and mineralization of pre-osteoblastic MC3T3-E1 cells accompanied by an increase in the expression of bone matrix proteins including ALP, ColI, OCN, and OPN. The osteoblastogenesis activity of L-quebrachitol is possibly mediated by triggering the BMP-2-responsive, Runx2, MAPK, and Wnt/ $\beta$-catenin signaling pathways. Interestingly, the biological activity of L-quebrachitol to promote osteoblastogenesis contrasts starkly with its closely related structural isomer, D-pinitol, which promotes the suppression of osteoclastogenesis. Notably, this is the first report of a new signaling pathway involved in the promotion of osteoblastogenesis induced by monomeric polyols. Although further studies are required to study the effect on osteoclastogenesis and to clarify the in vivo activity and mechanisms, L-quebrachitol might be a candidate for a bone formation-promoting supplement. Moreover, this study could lead to value-creation as well as value-adding to natural rubber latex serum from rubber factories.

\section{Materials and Methods}

\subsection{Materials}

Minimum essential medium alpha medium ( $\alpha$-MEM), RPMI-1640 phenol red-free medium and fetal bovine serum (FBS) were purchased from Gibco (Grand Island, NY, USA). $\beta$-Glycerophosphate, ascorbic acid, MTT (3-(4,5-dimethylthiazol-2-yl)-2,5-diphenyltetrazolium bromide), and cetylpyridinium chloride (CPC) were purchased from Sigma Chemical Co. (St. Louis, MO, USA). All other chemicals were of the grade quality available.

\subsection{Collection and Fractionation of Fresh Latex}

Fresh latex (7 L) was gathered in an ice-chilled beaker (Merck, Kenilworth, NJ, USA) from regularly tapped H. brasiliensis trees of the RRIM 600 clone. Latex coagulation was induced with the addition 
of $0.2 \%(v / v)$ aqueous formic acid. The rubber latex coagulum was squeezed through rollers to assemble the serum drainage. The collected serum, which contained $1.52 \mathrm{mg}$ of the ML-1 protein, was then concentrated 20-fold by ultrafiltration with a Pillicon ${ }^{\circledR}$ tangential flow ultrafiltration system (Millipore, Jaffrey, NH, USA) equipped with a $10 \mathrm{kDa}$ cutoff membrane cassette and operated under $20 \mathrm{psi}$ at room temperature. The $10 \mathrm{kDa}$ permeate stream was further filtered with a smaller pore size (1 kDa cutoff) to obtain a $1 \mathrm{kDa}$ permeate filtrate $(3.5 \mathrm{~L})$ and then concentrated with the mini spray dryer B-290 (BUCHI, New Castle, DE, USA) to collect the solid powder or $1 \mathrm{kDa}$ permeate powder $(100 \mathrm{~g})$ and was used as a starting material for L-quebrachitol purification.

\subsection{Purification of L-quebrachitol}

Fifty grams of $1 \mathrm{kDa}$ permeate powder was suspended in methanol at a ratio of 1:10 $(w / v)$ and stirred at room temperature for $24 \mathrm{~h}$. After this time, the insoluble components were removed by filtration with Whatman grade no. 1 filter paper (Fisher Scientific, Loughborough, Leicestershire, UK) and the filtrate obtained was concentrated at a $1 / 10$ volume by a rotary evaporator (BUCHI, New Castle, DE, USA) at $40-45{ }^{\circ} \mathrm{C}$. The resulting crystals were collected after $12 \mathrm{~h}$. Additionally, they were recrystallized three times with $75 \%$ aqueous ethanol to give a colorless crystal. After freeze-drying $(6.5 \mathrm{~g})$, the samples were dissolved in double the amount of distilled water before being desalted through a cation-exchange column on AG 50W-X2 (Bio-Rad, Hercules, CA, USA) $\left(5 \times 10 \mathrm{~cm}, \mathrm{H}^{+}\right.$form). The unbound fraction was washed with distilled water $(300 \mathrm{~mL})$, concentrated again by the rotary evaporator (BUCHI, New Castle, DE, USA), and then precipitated with cold ethanol (three volumes) at $4{ }^{\circ} \mathrm{C}$ overnight. The collected pellet, pure L-quebrachitol, was freeze-dried before further characterization (yield of $6.48 \pm 1.57 \% w / w$ of $1 \mathrm{kDa}$-permeate powder). The properties of the standard L-quebrachitol (Sigma-Aldrich, St. Louis, MO, USA) were confirmed through a comparison of chromatographic and spectroscopic data which included mass (Mass Spectrometer 2690, Milford, MA, USA), IR (Equinox 55, Bruker, Germany), and NMR spectra (Fourier Transform NMR Spectrometer 500 MHz, Unity Inova, Varian, Germany).

\subsection{Cell Culture and Differentiation}

The murine pre-osteoblastic cell line MC3T3-E1 (subclone 14 CRL-2593) was purchased from ATCC (Manassas, VA, USA). MC3T3-E1 cells were used in passage number 23 in all experiments. These early passage cells had not changed in morphology and osteoblastic function due to the long culture time [41]. Cells were cultured in $\alpha$-MEM with $10 \%$ FBS, 100 units $/ \mathrm{mL}$ of penicillin, and $100 \mu \mathrm{g} / \mathrm{mL}$ of streptomycin at $37{ }^{\circ} \mathrm{C}$ in a $5 \% \mathrm{CO}_{2}$ incubator (Thermo Fisher Scientific, Waltham, MA, USA). The culture medium was changed every 2-3 days. To induce differentiation, cells were cultured in osteogenic induction medium containing $1 \mathrm{M}$ of $\beta$-glycerophosphate and $50 \mu \mathrm{g} / \mathrm{mL}$ of ascorbic acid.

\subsection{Cytotoxicity Assay}

The MTT assay was performed to assess the cytotoxicity of L-quebrachitol. Cells were treated with L-quebrachitol at different concentrations. After treatment at 24 and $48 \mathrm{~h}$, cultured cells were washed with PBS. RPMI-1640 phenol red-free medium and $5 \mathrm{mg} / \mathrm{mL}$ of MTT were added, and the mixture was incubated at $37{ }^{\circ} \mathrm{C}$ for $3 \mathrm{~h}$. The formazan product was solubilized in acidic isopropanol, and the absorbance was measured at $570 \mathrm{~nm}$.

\subsection{Alkaline Phosphatase (ALP) Activity Assay}

Cells were treated with L-quebrachitol for 7 days. The lysate cell supernatant was collected for assay. Protein concentration was measured by the Pierce BCA Protein Assay Kit (Thermo Fisher Scientific, Waltham, MA, USA) and ALP activity was determined with a substrate containing $4 \mathrm{mg} / \mathrm{mL}$ of 4-nitrophenyl phosphate (4NPP) in $0.2 \mathrm{M}$ of 2-amino-2-methyl-1-propanol with $4 \mathrm{mM}$ of $\mathrm{MgCl}_{2}$ at $37^{\circ} \mathrm{C}$ for $30 \mathrm{~min}$. The reaction was stopped by $0.1 \mathrm{M} \mathrm{NaOH}$, and the absorbance of the yellow 
solution was measured at $405 \mathrm{~nm}$. The ALP activity was normalized to the protein concentration and the enzyme activity is shown as $\mu \mathrm{mole} / \mathrm{min} / \mathrm{mg}$ of protein.

\subsection{Alizarin Red S Staining}

Cells were treated with L-quebrachitol for 14 or 21 days. Calcium deposition was measured using Alizarin red S staining. Briefly, cells were washed with PBS and fixed with $10 \%$ formaldehyde for $15 \mathrm{~min}$. Cells were stained with $40 \mathrm{mM}$ of Alizarin red S solution (pH 4.1-4.3) in the shaker (Labnet International, Big flats, NY, USA) at room temperature for $30 \mathrm{~min}$. The non-specific staining was removed by washing with distilled water five times ( $5 \mathrm{~min} /$ time). Alizarin red $\mathrm{S}$ staining was dissolved by cetylpyridinium chloride (CPC) for quantification and the absorbance was measured at $550 \mathrm{~nm}$.

\subsection{Cell Cycle Analysis}

Cells treated with L-quebrachitol for $48 \mathrm{~h}$ were trypsinized, fixed in ice-cold $70 \%$ ethanol at $4{ }^{\circ} \mathrm{C}$ at least $30 \mathrm{~min}$, and washed with PBS after fixing. Then, propidium iodide containing RNase staining solution (Merck, New Jersey, USA) was added to determine the DNA content and incubated for $30 \mathrm{~min}$ at room temperature in the dark. Each sample $\left(1 \times 10^{6}\right.$ cells $)$ was analyzed by flow cytometry (Guava easyCyte ${ }^{\mathrm{TM}} \mathrm{HT}$, Hayward, CA, USA) to determine the percentages of G1, S, and G2 in the cell cycle.

\subsection{Quantitative Real-Time Polymerase Chain Reaction ( $q R T-P C R$ )}

The total RNA from cells treated with L-quebrachitol was extracted using the TriPure Isolation Reagent (Roche, Buonas, Switzerland). RNA $(1 \mu \mathrm{g})$ was reverse transcribed using the Transcriptor First Strand cDNA Synthesis Kit (Roche, Buonas, Switzerland) to cDNA according to the manufacturer's instruction. The qRT-PCR analysis was performed using the EvaGreen HRM Mix (Solis Biodyne, Tartu, Estonia), and the specific primers for the genes are listed in Table 1. GAPDH was used as an internal control. The relative expression ratio was calculated using the $2^{-\triangle \Delta \mathrm{Ct}}$ method.

Table 1. The primer sequences of qRT-PCR.

\begin{tabular}{|c|c|c|}
\hline Gene & Sequence & GenBank Accession No. \\
\hline \multirow{2}{*}{ RUNX2 } & F: GTGGCAGTGTCATCATCTGAAAT & \multirow{2}{*}{ NM_001145920.2 } \\
\hline & R: TCGCCTCAGTGATTTAGGGCGCA & \\
\hline \multirow{2}{*}{$O P N$} & F: GCTATCACCTCGGCCGTTGGGG & \multirow{2}{*}{ NM_001204203.1 } \\
\hline & R: CATTGCCTCCTCCCTCCCGGTG & \\
\hline \multirow{2}{*}{$A L P$} & F: ATGGAGGATTCCAGATACAGG & \multirow{2}{*}{ NM_007431.3 } \\
\hline & R: CCATGGTAGATTACGCTCACA & \\
\hline \multirow{2}{*}{ OCN } & F: CTGTGACATCCATACTTGCAGG & \multirow{2}{*}{ NM_001032298.3 } \\
\hline & R: TGCGCTCTGTCTCTCTGACC & \\
\hline \multirow{2}{*}{$B M P-2$} & F: GCTTCCGCTGTTTGTGTTTG & \multirow{2}{*}{ NM_007553.3 } \\
\hline & R: GGTCACAGATAAGGCCATTGC & \\
\hline \multirow{2}{*}{ COLI } & F: GCCTTTCCAGGTTCTCCAGCGG & \multirow{2}{*}{ NM_007742.4 } \\
\hline & R: TTCCCTGGTGCTGATGGTGTTGCT & \\
\hline \multirow{2}{*}{ ERK1 } & F: AAGCAGAGACCCCAGCAAAGTGAGAGAAG & \multirow{2}{*}{ NM_011952.2 } \\
\hline & R: GACACCCCTGTCCTTTTGGATCTGGTCCTG & \\
\hline \multirow{2}{*}{ ERK2 } & F: GTATGGGTGGGCCAGAGCCTGTTCAACTTC & \multirow{2}{*}{ NM_001357115.1 } \\
\hline & R: GGTGCCATGGAACAGGTTGTTCCCAAATGC & \\
\hline \multirow{2}{*}{ JNK1 } & F: GCATGGGTCTGATTCTGAAATG & \multirow{2}{*}{ NM_001310453.1 } \\
\hline & R: CTCAGGAGCTCAAGGAATAGTG & \\
\hline \multirow{2}{*}{ JNK2 } & F: AACTCTGCGGATGGTGTTC & \multirow{2}{*}{ NM_001163671.1 } \\
\hline & R: GGTCCTCCATAAAGTCCTGTTC & \\
\hline \multirow{2}{*}{$p 38 \alpha$} & F: AGGCCATGGTGCATGTGTGT & \multirow{2}{*}{ NM_001357724.1 } \\
\hline & R: AGTAGCTGGAGGAGGAGGAG & \\
\hline
\end{tabular}


Table 1. Cont.

\begin{tabular}{|c|c|c|}
\hline Gene & Sequence & GenBank Accession No. \\
\hline \multirow{2}{*}{ LRP5 } & F: TTGACCTTGTGGACCCTTTC & \multirow{2}{*}{ NM_008513.3 } \\
\hline & R: GAGGACAAGCTCCCACATATT & \\
\hline \multirow{2}{*}{$\beta$-catenin } & F: TCAAGTGAAACCGGGCTATC & \multirow{2}{*}{ NM_007664.5 } \\
\hline & R: CTCCAACGGGCATCTTCATTA & \\
\hline \multirow{2}{*}{ Wnt5a } & F: ATATCAGGCACCATTAAACCA & \multirow{2}{*}{ NM_009524.4 } \\
\hline & R: CACTTAGGGGTTGTTCTCTGA & \\
\hline \multirow{2}{*}{$F z d 4$} & F: GCACATTGGCACATAAACCGAAC & \multirow{2}{*}{ NM_008055.4 } \\
\hline & R: GGCTACAACGTGACCAAGATGCC & \\
\hline \multirow{2}{*}{ GAPDH } & F: GAATTTGCCGTGAGTGGAGT & \multirow{2}{*}{ NM_001289726.1 } \\
\hline & R: AAATGGTGAAGGTCGGTGTG & \\
\hline
\end{tabular}

Notes: $R U N X 2$ = runt-related transcription factor 2; OPN = osteopontin; $A L P=$ alkaline phosphatase; $O C N=$ osteocalcin; $B M P-2$ = bone morphogenetic protein $2 ; C O L I=$ collagen type $1 ; E R K 1=$ extracellular signal-regulated kinases $1 ; E R K 2=$ extracellular signal-regulated kinases $2 ; \quad J N K 1=$ jun $\mathrm{n}$-terminal kinase $1 ; \quad J N K 2=$ jun n-terminal kinase 2; $L R P 5=$ low-density lipoprotein receptor-related protein 5; $p 38 \alpha=\mathrm{p} 38$ mitogen-activated protein kinases $\alpha ; \beta$-catenin = Beta-catenin; $W n t 5 a=$ wingless-type MMTV integration site family, member $5 \mathrm{~A} ; F z d 4=$ Frizzled 4 and $G A P D H=$ glyceraldehyde-3-phosphate dehydrogenase.

\subsection{Western Blot Analysis}

MC3T3-E1 cells treated with L-quebrachitol for the indicated time were lysed with lysis buffer, and the concentration of protein was measured with a protein assay kit (Bio-Rad, Hercules, CA, USA). For Western blotting, each sample was separated on a 10\% SDS-PAGE gel, followed by transfer to nitrocellulose membranes (Amersham Pharmacia Biotech, Amersham Buckinghamshire, UK) by electroblotting. The membranes were blocked for nonspecific binding in $5 \%$ non-fat dried milk in TBS for 1h. BMP-2 and Runx2 expressions were detected by incubation with their specific primary antibodies, anti-BMP-2 (Abcam, Milton, UK) and anti-Runx2 (Cell Signaling Technology, Beverly, MA, USA) for $2 \mathrm{~h}$. After washing with TBS-Tween 3 times, specific protein bands were probed with an Alexa infrared dye-conjugated secondary antibody (Invitrogen, Carlsbad, CA, USA) and visualized by the Odyssey Infrared Imaging System (LI-CORE) in accordance with the manufacturer's instructions.

\subsection{Statistical Analysis}

Data were presented as the mean \pm standard error of the mean (SEM). All the results of the experiments were analyzed with the SPSS 23 statistical software (SPSS Inc., Chicago, IL, USA). The significance was analyzed by one-way analysis of variance (ANOVA), followed by Duncan's multiple range test. $p$ values $<0.05$ were considered statistically significant.

\section{Conclusions}

In conclusion, we reported, for the first time, that L-quebrachitol promotes osteoblast proliferation, differentiation, and mineralization, possibly through the involvement of the BMP, MAPK, and $\mathrm{Wnt} / \beta$-catenin signaling pathways. In addition, a method to obtain purified L-quebrachitol as a byproduct from Hevea latex serum was reported.

Author Contributions: T.P., U.K.-L., and C.S. conceived and designed the experiments. T.Y. performed the experiments. T.P. and T.Y. drafted the original manuscript. U.K., C.S., and R.W. modified the manuscript. All authors read and approved the final manuscript.

Funding: This research was funded by grants from Prince of Songkla University, contract no.SCI570530S and through the government budget, Scholarship Awards for Thai Ph.D. Students under Thailand's Education Hub for the Southern Region of ASEAN Countries (Grant No. PHD/2557 to Thanintorn Yodthong) and Scholarhip for an Overseas Thesis Research Study (to Thanintorn Yodthong), the Graduate School and the Academic Strengthening Program in Biochemistry, Faculty of Science. It was also funded by the Thailand Centre of Excellence for Life Sciences (Public Organization).

Conflicts of Interest: The authors declare no conflict of interest. 


\section{References}

1. Hadjidakis, D.J.; Androulakis, I.I. Bone remodeling. Ann. N. Y. Acad. Sci. 2006, 1092, 385-396. [CrossRef] [PubMed]

2. Masi, L. Epidemiology of osteoporosis. Clin. Cases Miner. Bone MeTable 2008, 5, 11-13.

3. An, J.; Yang, H.; Zhang, Q.; Liu, C.; Zhao, J.; Zhang, L.; Chen, B. Natural products for treatment of osteoporosis: The effects and mechanisms on promoting osteoblast-mediated bone formation. Life Sci. 2016, 147, 46-58. [CrossRef] [PubMed]

4. Franceschi, R.T.; Ge, C.; Xiao, G.; Roca, H.; Jiang, D. Transcriptional regulation of osteoblasts. Ann. N. Y. Acad. Sci. 2007, 1116, 196-207. [CrossRef] [PubMed]

5. Shin, H.D.; Yang, K.J.; Park, B.R.; Son, C.W.; Jang, H.J.; Ku, S.K. Antiosteoporotic effect of polycan, $\beta$-glucan from Aureobasidium, in ovariectomized osteoporotic mice. Nutrition 2007, 23, 853-860. [CrossRef] [PubMed]

6. Lee, D.H.; Han, D.-W.; Park, B.J.; Baek, H.S.; Takatori, K.; Aihara, M.; Tsubaki, K.; Park, J.-C. The influences of $\beta$-glucan associated with BMP-7 on MC3T3-E1 proliferation and osteogenic differentiation. Key Eng. Mater. 2005, 288-289, 241-244. [CrossRef]

7. Wittrant, Y.; Gorin, Y.; Woodruff, K.; Horn, D.; Abboud, H.E.; Mohan, S.; Abboud-Werner, S.L. High $\mathrm{D}(+)$ glucose concentration inhibits RANKL-induced osteoclastogenesis. Bone 2008, 42, 1122-1130. [CrossRef] [PubMed]

8. Xu, J.; Yue, F.; Wang, J.; Chen, L.; Qi, W. High glucose inhibits receptor activator of nuclear factor- $\kappa \mathrm{B}$ ligand-induced osteoclast differentiation via downregulation of v-ATPase V0 sSubunit D2 and dendritic cell specific transmembrane protein. Mol. Med. Rep. 2015, 11, 865-870. [CrossRef] [PubMed]

9. Yamada, K.; Noguchi, C.; Kamitori, K.; Dong, Y.; Hirata, Y.; Hossain, M.A.; Tsukamoto, I.; Tokuda, M.; Yamaguchi, F. Rare sugar D-allose strongly induces thioredoxin-interacting protein and inhibits osteoclast differentiation in Raw264 Cells. Nutr. Res. 2012, 32, 116-123. [CrossRef] [PubMed]

10. Takeuchi, T.; Nagasaka, M.; Shimizu, M.; Tamura, M.; Arata, Y. N-Acetylglucosamine suppresses osteoclastogenesis in part through the promotion of O-GlcNAcylation. Bone Reports 2016, 5, 15-21. [CrossRef] [PubMed]

11. Takeuchi, T.; Sugimoto, A.; Imazato, N.; Tamura, M.; Nakatani, S.; Kobata, K.; Arata, Y. Glucosamine suppresses osteoclast differentiation through the modulation of glycosylation including O-GlcNAcylation. Biol. Pharm. Bull. 2017, 40, 352-356. [CrossRef] [PubMed]

12. Lv, C.; Wang, L.; Zhu, X.; Lin, W.; Chen, X.; Huang, Z.; Huang, L.; Yang, S. Glucosamine promotes osteoblast proliferation by modulating autophagy via the mammalian target of rapamycin pathway. Biomed. Pharmacother. 2018, 99, 271-277. [CrossRef] [PubMed]

13. Asai, H.; Nakatani, S.; Kato, T.; Shimizu, T.; Mano, H.; Kobata, K.; Wada, M. Glucosamines attenuate bone loss due to menopause by regulating osteoclast function in ovariectomized mice. Biol. Pharm. Bull. 2016, 39, 1035-1041. [CrossRef] [PubMed]

14. Del Mar Arriero, M.; Ramis, J.M.; Perelló, J.; Monjo, M. Inositol hexakisphosphate inhibits osteoclastogenesis on RAW 264.7 Cells and human primary osteoclasts. PLOS ONE 2012, 7. [CrossRef]

15. Addison, W.N.; McKee, M.D. Inositol hexakisphosphate inhibits mineralization of MC3T3-E1 osteoblast cultures. Bone 2010, 46, 1100-1107. [CrossRef] [PubMed]

16. Grases, F.; Sanchis, P.; Prieto, R.M.; Perelló, J.; López-González, Á.A. Effect of tetracalcium dimagnesium phytate on bone characteristics in ovariectomized rats. J. Med. Food 2010, 13, 1301-1306. [CrossRef] [PubMed]

17. Liu, S.C.; Chuang, S.M.; Tang, C.H. D-pinitol inhibits RANKL-induced osteoclastogenesis. Int. Immunopharmacol. 2012, 12, 494-500. [CrossRef] [PubMed]

18. Wang, D.; Zhang, S.; Chang, Z.; Kong, D.-X.; Zuo, Z. Quebrachitol: Global Status and basic research. Nat. Products Bioprospect. 2017, 7, 113-122. [CrossRef] [PubMed]

19. Nguyen, L.A.; He, H.; Pham-Huy, C. Chiral drugs: An overview. Int. J. Biomed. Sci. 2006, 2, 85-100. [PubMed]

20. Wang, Q.; Alén, M.; Nicholson, P.H.F.; Halleen, J.M.; Alatalo, S.L.; Ohlsson, C.; Suominen, H.; Cheng, S. Differential effects of sex hormones on peri- and endocortical bone surfaces in pubertal girls. J. Clin. Endocrinol. MeTable 2006, 91, 277-282. [CrossRef] [PubMed] 
21. Kim, J.L.; Kang, S.W.; Kang, M.K.; Gong, J.H.; Lee, E.S.; Han, S.J.; Kang, Y.H. Osteoblastogenesis and osteoprotection enhanced by flavonolignan silibinin in osteoblasts and osteoclasts. J. Cell. Biochem. 2012, 113, 247-259. [CrossRef] [PubMed]

22. Lee, S.U.; Shin, H.K.; Min, Y.K.; Kim, S.H. Emodin accelerates osteoblast differentiation through phosphatidylinositol 3-kinase activation and bone morphogenetic protein-2 gene expression. Int. Immunopharmacol. 2008, 8, 741-747. [CrossRef] [PubMed]

23. Zhang, R.; Oyajobi, B.O.; Harris, S.E.; Chen, D.; Tsao, C.; Deng, H.W.; Zhao, M. Wnt/ $\beta$-catenin signaling activates bone morphogenetic protein 2 expression in osteoblasts. Bone 2013, 52, 145-156. [CrossRef] [PubMed]

24. Wititsuwannakul, D.; Chareonthiphakorn, N.; Pace, M.; Wititsuwannakul, R. Polyphenol oxidases from latex of Hevea brasiliensis: Purification and characterization. Phytochemistry 2002, 61, 115-121. [CrossRef]

25. Sritanyarat, W.; Pearce, G.; Siems, W.F.; Ryan, C.A.; Wititsuwannakul, R.; Wititsuwannakul, D. Isolation and characterization of isoinhibitors of the potato protease inhibitor I family from the latex of the rubber trees, Hevea brasiliensis. Phytochemistry 2006, 67, 1644-1650. [CrossRef] [PubMed]

26. Kanokwiroon, K.; Teanpaisan, R.; Wititsuwannakul, D.; Hooper, A.B.; Wititsuwannakul, R. Antimicrobial activity of a protein purified from the latex of Hevea brasiliensis on oral microorganisms. Mycoses 2008, 51, 301-307. [CrossRef] [PubMed]

27. Pitakpornpreecha, T.; Plubrukarn, A.; Wititsuwannakul, R. Quantification of 5'-Deoxy-5'-methylthioadenosine in heat-treated natural rubber latex serum. Phytochem. Anal. 2012, 23, 12-15. [CrossRef] [PubMed]

28. Sukprasirt, P.; Wititsuwannakul, R. A Chitinolytic Endochitinase and $\beta-N$-acetylglucosaminidase-based system from Hevea latex in generating $N$-acetylglucosamine from chitin. Phytochemistry 2014, 104, 5-11. [CrossRef] [PubMed]

29. Van Alphen, J. Quebrachitol. Ind. Eng. Chem. 1951, 43, 141-145. [CrossRef]

30. Don, M.J.; Lin, L.C.; Chiou, W.F. Neobavaisoflavone stimulates osteogenesis via p38-mediated up-regulation of transcription factors and osteoid genes expression in MC3T3-E1 Cells. Phytomedicine 2012, 19, 551-561. [CrossRef] [PubMed]

31. Bronckers, A.L.J.J.; Engelse, M.A.; Cavender, A.; Gaikwad, J.; D'Souza, R.N. Cell-specific patterns of Cbfa1 mRNA and protein expression in postnatal murine dental tissues. Mech. Dev. 2001, 101, 255-258. [CrossRef]

32. Kim, M.B.; Song, Y.; Hwang, J.K. Kirenol stimulates osteoblast differentiation through activation of the BMP and Wnt/ $\beta$-catenin signaling pathways in MC3T3-E1 Cells. Fitoterapia 2014, 98, 59-65. [CrossRef] [PubMed]

33. MacDonald, B.T.; Tamai, K.; He, X. Wnt/beta-catenin signaling: Components, mechanisms, and diseases. Dev. Cell. 2009, 17, 9-26. [CrossRef] [PubMed]

34. Monroe, D.G.; McGee-Lawrence, M.E.; Oursler, M.J.; Westendorf, J.J. Update on Wnt signaling in bone cell biology and bone disease. Gene 2012, 492, 1-18. [CrossRef] [PubMed]

35. Fujita, K.I.; Janz, S. Attenuation of WNT signaling by DKK-1 and -2 regulates BMP2-induced osteoblast differentiation and expression of OPG, RANKL and M-CSF. Mol. Cancer 2007, 6, 1-13. [CrossRef] [PubMed]

36. Tian, Y.; Xu, Y.; Fu, Q.; He, M. Parathyroid hormone regulates osteoblast differentiation in a Wnt/ $\beta$-catenin-dependent manner. Mol. Cell. Biochem. 2011, 355, 211-216. [CrossRef] [PubMed]

37. Hipskind, R.A.; Bilbe, G. MAP kinase signaling cascades and gene expression in osteoblasts. Front Biosci. 1998, 3, 804-816. [CrossRef]

38. Suzuki, A.; Guicheux, J.; Palmer, G.; Miura, Y.; Oiso, Y.; Bonjour, J.P.P.; Caverzasio, J. Evidence for a role of p38 MAP kinase in expression of alkaline phosphatase during osteoblastic cell differentiation. Bone 2002, 30, 91-98. [CrossRef]

39. Celil, A.B.; Campbell, P.G. BMP-2 and insulin-like growth factor-I mediate osterix (Osx) expression in human mesenchymal stem cells via the MAPK and protein kinase D signaling pathways. J. Biol. Chem. 2005, 280, 31353-31359. [CrossRef] [PubMed] 
40. Zhang, W.; Liu, H.T. MAPK signal pathways in the regulation of cell proliferation in mammalian cells. Cell Res. 2002, 12, 9-18. [CrossRef] [PubMed]

41. Chung, C.Y.; Iida-Klein, A.; Wyatt, L.E.; Rudkin, G.H.; Ishida, K.; Yamaguchi, D.T.; Miller, T.A. Serial passage of MC3T3-E1 cells alters osteoblastic function and responsiveness to transforming growth factor- $\beta 1$ and bone morphogenetic protein-2. Biochem Biophys Res Commun. 1999, 265, 246-251. [CrossRef] [PubMed]

Sample Availability: Samples of the compounds are available from the authors.

(C) 2018 by the authors. Licensee MDPI, Basel, Switzerland. This article is an open access article distributed under the terms and conditions of the Creative Commons Attribution (CC BY) license (http://creativecommons.org/licenses/by/4.0/). 